\title{
The Indonesian Traditional Healer Accountability in the Law and Culture Perspectives
}

\author{
Prilian Cahyani \\ Criminal Law Department, Law Faculty, Universitas Airlangga, Surabaya, Indonesia \\ Email: prillian@fh.unair.ac.id
}

\begin{abstract}
The aim of this study is to analyse the Indonesian traditional healer accountability in the law and culture perspectives. The traditional healing has been existed in Indonesian since many years ago. Moreover, they are known as part of Indonesian tradition because they are developed over generations. There are many kind of the traditional healing existed. In Indonesia, the traditional healing practices are legal. Since most of Indonesian people are not well educated, the traditional healing practice still become their first choice of health problem.This study discusses the traditional healing accountability in Indonesia based on the law and the culture perspective. There are 3 legal regulations related to the traditional healing accountability in Indonesia. These are the Law No. 36 / 2009 on Health, the Law No. 36/2014 on Health Care Personnel and the Indonesian Government Regulation No. 103/2014 on Traditional Health Service. Traditional healing is also known as "alternative healing practice". As the results of those regulations, many of Indonesian healer are practicing among communities, using their variable of healing practices between them. Unfortunately, inappropriate practices could result in poor or devastating effects. Based on that background, this article will answear two questions. Firstly, how is the Indonesia government regulate the tradisional healing ?. Secondly, how is the Indonesian traditional healer accountability ?.This study concludes that Indonesian government urgently needs to improve their control to the practices of the traditional healing although in Indonesia has been regulated that in the Indonesian regulation. Therefore, the Indonesian government should support the establishment of the Indonesian traditional healer community in order to improve the qualification and skill of the traditional Indonesian healer and ethics council. The government should support the traditional Indonesian healer provides affordable training. The sanctions that can be imposed on traditional healers for wrongful act are legal sanctions such as administrative, civil and criminal sanction.
\end{abstract}

Keywords--- accountability; traditional healing; Law

\section{INTRODUCTION}

Health is a basic of human right. Therefore the state has an obligation to fulfil the right to health of the citizens. In the 1945 Constitution, the right to health is provided for in Article $28 \mathrm{H}$ paragraf (1) which states that "every person shall have the right to live a prosperous life both materially and spiritually, to reside [in the country], and to enjoy a good and healthy environment, as well as have the right to access healthcare services. Meanwhile, the obligation of the state to fulfil this right is provided for in Article 34 paragraph (3) of the 1945 Constitution which states that "the state shall be responsible for the provision of goodhealthcare services and public service facilities".

In seeking healthcare, there are different options people can use, one of which is healthcare treatment with the help of medical personnel. Medical personnel that can help with the treatment of illnesses are doctors, both general practitioners and specialists. In the concept of legal relation between doctors and patients, any kind of medical procedures performed by the doctor on their patient is certainly very clear and measurable, with the skills and knowledge acquired through formal and medical education.The profession of a doctor when performing medical procedures has also been regulated. Likewise, legal protection of the patient has also been specifically regulated by the Law No. 29 of 2004 on the Medical Practice.

The devolepment of science and technology has affected the development of the system of traditional healing. That can be seen from the fact that today we have a special education that teaches traditional healing, while the person practicing is called a traditional healer. This is specifically regulated by the Law No. 36of 2014 on Health Workers.

Currently, traditional healing is widespread in the society. This can be seen in the frequent appearance of advertisements of traditional healingin mass media, both electronic and print. However, the inclusion of traditional healing in the Health Law is actually accompanied by some notes that can be considered as juridical problems, for which a solution should be found. Some of the notes of the problems read as follows: Firstly, the absence of standard methods of traditional medicine; Secondly, there is still no clarity with respect to the position of traditional healer as a profession, because to the considered on the job needs to be 
done by a professional. Moreover, there is no organization such as an honorarycouncil or an ethics council is evidenceof good governance of the profession. Thirdly, there is no clarity with respect to the legal relations between traditional healing practitioners and their clients. Whereas from the legal perspective established legal relations will entail legal liability. Based on the background described above, the author herein presents the formulation of the problem as follows : How is the legal liability of traditional healer addressed?

\section{TRADITIONAL HEALING PRACTITIONERS}

Up until the present time, the existence of the centuries-old traditional healing has not shown any sign to recede. On the contrary, it has thrived even more, just like modern medicine. So is the case in Indonesia. This is because traditional healing has several advantages as follows:

a. It uses a holistic approach in treating clients. In a holistic approach, a client's illness is not only attributed to their physical environment, but also to all aspects of the patient's life including the social and spiritual aspects [7].

b. Treatment is done until completed. Clients are treated until all procedures are completed [7].

c. Practice hours are not limited [7].

d. Service is integrated. In traditional medicine, there are healing and treatment. Both are carried out simultaneously [7].

e. It has a sense of familiarity, and is informal [7].

f. Fee is adjusted to the client's ability [7].

g. It is passed down from generation to generation [7].

In Indonesia, traditional healing is already specifically regulated under the Health Law. In the Law, traditional healing is referred to as traditional healthcare services. The definition of traditional healthcare services is provided in Article 1 item 16 which states that, "traditional healthcare services means medication and/or treatment using means and medications that are based on experience and skills empirically passed down through generations that can be accounted for and practiced in accordance with the norms prevailing in society."

In terms of the means of treatment, traditional healthcare services are categorized into two groups, namely the traditional healthcare services that use skills, and traditional healthcare services that use herbs. This categorization is provided for in Article 59 of the Health Law. In the implementation of traditional healthcare services, the Government has the duty to provide oversight and regulation. This is provided for in Article 59 paragraph 2 and Article 61 of the Health Law. Oversight is carried out in order not to let the implementation of traditional healthcare services be contradicting to religious norms.

On the other hand, the matter of traditional healthcare workers is provided for in the provisions of the Law on Health Workers, in particular Article 11. The traditional healthcare workers referred to in the provision are those who have the ability to provide traditional healthcare services through formal education equivalent to Diploma III education. Traditional healthcare workers include those who use skills and those who use herbs as the means of treatment.

To make oversight easy, the Government has put in efforts to provide direction and facilitate the foundation of an association of traditional healing. Based on the results of the research, in East Java there are already 9 associations of traditional healing. Nevertheless, many of them refused to be a member of the associations for economic reasons.

Through these associations, direction was provided in formulating a code of ethics. However, in practice, up until now, noethics council has been established for traditional healing. The absence of this council may in the coming days causes an obstacle in assessing the standard of the provision of traditional healing due to the absence of authorized organization to conduct such assessment.

In Indonesia there are several professions of health care providers, especially traditional healing who already have associations and codes of ethics. The existing codes of ethics in traditional healing in Indonesia are among others, the code of ethics of traditional massage therapists, the code of ethics of cupping therapist association, the code of ethics of reflexology therapist association, the code of ethics of reiki practitionerassociation, and the code of conduct of the Indonesian accupressure practitioners. Imposition of ethical sanctions is the authority of the honorary ethics council of the profession concerned. This council is responsible for examining, deciding and imposing sanctions for violations of the code of ethics.

\section{LIABILITY}

There are possibilities of medical errors occurring in traditional healing provided by traditional healer. Elements that can be used as parameters to determine the presence of any medical error can be seen from the legal and ethical aspects of the profession. Law is a system created to control people's behavior and put limits on them to maintain order. Van Bemmelen as quoted by Syachrul Mahmud in his book states that the purpose of law is to maintain order, harmony, prosperity and peace in society without deliberately causing suffering [8]. From this definition, it can be understood that one of the purposes of law is to maintain order. With respect to this, what can be done is to fulfill lthe obligation to account for actions that violate the law because such actions will threaten the achievement of the purpose of the law. Legal liability can be reviewed from administrative law, civil law and criminal law. These three aspects of law have different forms of sanctions.

Discussion about traditional healer'liability in providing traditional healthcare includes ethical liabilityand legal liability. Ethical liability differs from legal liability. Professional ethical liability views problems from an ethical point of view. The sanctions that can be imposed for people who violate professional ethics are ethical sanctions. Meanwhile, administrative law puts more emphasize the aspect of authority, which refers to whether traditionalhealer who perform treatment on clients have legitimate authority to provide treatment. On the other hand, the civil law puts more emphasis on whether 
traditional healer have been providing proper service in accordance withservice standards. Whereas, the criminal law focuses on whether traditional healer in providing services in the form of traditional healing because medical errors, either negligent or intentional.

The profession of traditional healerneeds a code of ethics that must be adhered by all of its members. However, in practice, not all traditional healerhave registered themselves as a member of those profession. Based on the result of interviews with the head of Healthcare Service Department of East Java Provincial Health Office, traditional healer are reluctant to register themselves as a member of a professionbecause they will have to pay for professional membership dues. This can be an obstacle for some members of the profession [6]. In addition to that, the fact that the absence of ethics council also causes a constraint in the imposition of ethical sanctions.

Administrative legal sanctions are imposed ontraditional healer who violate theadministrative law. Administrative sanctions for traditional healerare regulated under Health Law and Government Regulation No. 103 of 2014 on Traditional Healthcare Services. Meanwhile, administrative sanctions for health workers, especially traditional health workers are regulated under Law No. 36 of 2014 on Health Workers.

With respect to traditional healing provided, traditional healer may be held accountable for their civil actions. Basically, civil liability aims to seek compensation for losses suffered [1]. Civil sanctions that can be imposed on traditional medicine healer, their violation in providingtraditional medicationare default or torts.

Default claim arisesin the event of failure of traditional healer providing the agreed medication. Default in traditional medicine occurs when the following criteria are fulfilled:

a. The relationship between a traditional healer and a client is based on a contract;

b. Traditional healer has undertaken inappropriate medicationor any treatment that is not based on the contract;

c. The client suffers losses due to the traditional healer's action [4].

The legal basis of default claim due to the non-compliance or breach of contract is provided for in Article 1239 of the Indonesia Civil Code which states that:"under any contract which outlines the performance of certain obligations and the prohibitions from conducting certain actions, in the event that a debtor fails to fulfill any of his/her obligation, the debtor concerned must fulfill his/her obligation to provide compensation or damages for the loss and the interest."

A tort claim could also be filed againsttraditional healer. With respect to tort claims, there are several conditions that must be fulfilled to determine if a person commits a tort. These conditions include the presence of an unlawful act, a wrongful act, the loss caused and the connection between the wrongful act and the loss suffered by the claimant. [8] Tort claims are based on fault liability as outlined in the provisions of Articles 1365, 1366 and 1367 of the Indonesia Civil Code.
Criminal sanctions that may be imposed on traditional healer include criminal sanctions as regulated under the Health Law, Law No. 36 of 2014 on Health Workers. Both laws have specifically regulated criminal sanctions that can be imposed on traditional healer who commit a wrongful act either intentional or negligent.

Traditional healer may be subject to criminal provisions as outlined in article 84 , article 85 and article 86 of Law No. 36 of 2014 on Health Workers. Article 84 outlines gross negligence resulting in serious injury or even death. The imposed sanction is imprisonment. Article 85 regulates the intentional act of practicing without a registration certificate. Sanctions that may be imposed are criminal penalties. Article 86 provides for sanctions that can be imposed on traditional healer who conduct unauthorized practices. The offenders can be subject to penalty.

Traditional healer must also comply with criminal provisions as outlined in Article 191 of the Health Law which regulates the use of tools or equipment and technology in the practice of traditional healing. If the use of such technology leads to loss of property, serious injury or death, the offender will be subject to imprisonment and penalty.

\section{CONCLUSION}

In Indonesia, the traditional healing is recognized by the society as one of the means to cure diseases. The traditional healer have the ability to provide treatment with the knowledge which they acquire either from their ancestors or through formal education. Therefore, the Indonesian government should support traditional healer by providing affordable training for traditional healers in order to improve the qualification and skill of the traditional Indonesian healer.

Traditional healing have been legally regulated under the Health Law, the Law on Health Workers and Government Regulation Traditional Healing Services. In practice, the Government, both the Central Government and the Regional Government have an obligation to conduct oversight over the practice of traditional healing. In order to facilitate the oversight, the government has encouraged the establishment of traditional healerassociations.

Based on the result of this study, it was found that there have been several traditional healer association acknowledged by the Ministry of Health. The traditional healer association are currently directed and guided to prepare a code of ethics. Unfortunately, not all traditional healers join these association. In addition, up until now there is no honorary ethics council that has an authority to impose ethical sanctions.Therefore, the Indonesian goverenment should support establishment of the Indonesian traditional healer community / association and ethics council.

In practice, the sanctions that can be imposed on traditional healers for wrongful act are legal sanctions. Legal liability in this respect includes aspects of administrative law, civil law and criminal law. Administrative legal sanction will be imposed if traditional 
healer violate administrative provisions. Civil sanctions will be imposed for default and torts. Meanwhile, criminal sanctions will be applied on traditional healer in the even that they commit a wrongful act either intentional or negligent.

\section{REFERENCES}

[1] Anny Isfandyarie, Tanggung Jawab Hukum dan Sanksi Bagi Dokter Buku I, Prestasi Pustaka, Jakarta, 2006, page 6.

[2] Bryan A.Garner, Balck's Law Dictionary, Deluxe Eight Edition, St. Paul: Thomson West, 2004, p 1429.

[3] Bryan A.Garner, Balck's Law Dictionary, Deluxe Eight Edition, St. Paul: Thomson West, 2004, p 1429.

[4] Bahder Johan Nasution, Hukum Kesehatan Pertanggungjawaban Dokter, Rineka Cipta, Jakarta, 2013, page 63.

[5] Johnny Ibrahim, Teori \& Metodologi Penelitian Hukum Normatif, Malang, Bayumedia Publishing, 2008, pp 310-320.

[6] Result of the interview with Head of Healthcare Service Department of East Java Provincial Health Office

[7] Soekidjo Notoatmodjo, Etika dan hukum Kesehatan, Rineka Cipta, 2010, p 187.

[8] Syahrul Machmud, Penegakan Hukum dan Perlindungan Hukum Bagi Dokter Yang Diduga Melakukan Medikal Malpraktik, Karya Putra Darwati, Bandung, 2012, page 202. 